\title{
Commensal vs. parasitic relationship between Carapini fish and their hosts: some further insight through $\delta^{13} \mathrm{C}$ and $\delta^{15} \mathrm{~N}$ measurements
}

\author{
Eric Parmentier ${ }^{\mathrm{a}, \mathrm{b}, *}$, Krishna Das ${ }^{\mathrm{c}}$ \\ ${ }^{a}$ Laboratory of Functional and Evolutionary Morphology, University of Liège, \\ B6c, Sart-Tilman, B-4000 Liège, Belgium \\ ${ }^{\mathrm{b}}$ Centre de Recherche Insulaire et Observatoire de l'Environnement, C.R.I.O.B.E/E.P.H.E, \\ B.P. 1013, Moorea, French Polynesia \\ ${ }^{c}$ MARE Center, Laboratory for Oceanology, University of Liège, B6c, \\ Sart-Tilman, B-4000 Liège, Belgium
}

Received 14 January 2004; received in revised form 15 February 2004; accepted 30 March 2004

\begin{abstract}
In the Moorea Lagoon (French Polynesia), the pearlfish Carapus boraborensis, Carapus homei, Carapus mourlani and Encheliophis gracilis are generally found inside echinoderm hosts such as the holothurian Bohadschia argus and the starfish Culcita novaeguineae. At the end of their larval stage, these fish settle on the reef and directly enter their echinoderm host where they undergo an important metamorphosis. The aim of this study was to get further insight on the type of symbiosis (commensal vs. parasite) between these fish and their hosts. $\delta^{15} \mathrm{~N}$ and $\delta{ }^{13} \mathrm{C}$ measurements were determined in the tissues of invertebrate hosts (holothurians and starfish) and carapids (larvae, juveniles and adults). The obtained isotopic signatures reveal different kinds of associations: metamorphosing larvae, juveniles and adults of C. boraborensis and $C$. homei do not feed at all on host holothurian tissues, C. mourlani and its asterian host display a commensal relationship without any feeding association, while E. gracilis is likely to feed on the tissue of the holothurian.
\end{abstract}

(C) 2004 Elsevier B.V. All rights reserved.

Keywords: Carapidae; Stable isotopes; Diet; Larvae; Commensal; Parasite

* Corresponding author. Laboratory of Functional and Evolutionary Morphology, University of Liège, B6c, Sart-Tilman, B-4000 Liège, Belgium. Tel.: +32-4366-5024; fax: +32-4366-3715.

E-mail address: E.Parmentier@ulg.ac.be (E. Parmentier). 


\section{Introduction}

The fish of the Carapini tribe (Carapus sp. and Encheliophis sp., Carapidae) are able to penetrate and stay inside different invertebrate hosts such as echinoderms (sea cucumber, starfish) or bivalves. Stomach content analysis (Trott, 1970; Murdy and Cowan, 1980; Vanden Spiegel and Jangoux, 1989) and the musculo-skeletal descriptions of the buccal and pharyngeal jaws (Parmentier et al., 1999, 2000a,b) have suggested different kinds of symbiosis, depending on the species. Adults of Carapus species are commensal, using their host as a shelter and leaving it to hunt small prey, such as annelids, crustaceans (shrimp, decapod, amphipod) and small fish (Trott, 1970; MeyerRochow, 1979; Vanden Spiegel and Jangoux, 1989; Parmentier et al., 2000a,b). They can also be cannibalistic, feeding on other carapids within their host (pers. obs.). However, various authors have suggested that these fish could be parasites in their sub-adult stages (Arnold, 1953; Jangoux, 1974; Gustato, 1976; Trott, 1981). In contrast, Encheliophis sp. has been described as parasitic, feeding on the internal tissues of their host, mainly the gonads (Smith, 1964; Trott, 1970, 1981; Trott and Trott, 1972; Murdy and Cowan, 1980).

The larvae of Carapus and Encheliophis have a complex life cycle, with a planktonic phase followed by a benthic life phase, like most fish species of coral reefs (McCormick and Makey, 1997; Bonhomme and Planes, 2000; Leis and McCormick, 2002). Their life cycle may be divided into four stages: (1) the vexillifer larval stage, which is characterised by a complex specialisation of the dorsal fin (Olney and Markle, 1979; Govoni et al., 1984); (2) the tenuis stage, which is marked by a considerable lengthening of the body; (3) the juvenile stage, which is reached after a $60 \%$ shortening of the tenuis body length (Smith et al., 1981; Markle and Olney, 1990; Parmentier et al., 2002b), and finally (4) the adult stage. The first penetration into a host occurs during the tenuis stage. In Carapus homei, this first contact corresponds to a period of metamorphosis that lasts approximately 15 days. Darkness is necessary to initiate metamorphosis in Carapidae (Parmentier et al., in press). The otoliths of the tenuis maintained in daylight for 21 days possessed a transition zone of 21 increments and were not metamorphosed, whereas tenuis reared in darkness for 21 days had more than 80 increments after metamorphosis achievement. Fish were not fed during these experiments, meaning that metamorphosing fish could benefit from the material released by body reduction in order to use it in the development of the bones and the otoliths (Parmentier et al., in press).

Stomach content data reflect the most recent meal and may not be representative of overall diet. The morphofunctional and the ecomorphological characteristics of the buccal apparatus provide indications of a fish feeding ecology (Norton et al., 1995; Motta et al., 1995; Wainwright, 1998). The use of stable isotope ratios of carbon $\left({ }^{13} \mathrm{C} /{ }^{12} \mathrm{C}\right)$ and nitrogen $\left({ }^{15} \mathrm{~N} /{ }^{14} \mathrm{~N}\right)$ provides complementary data to the analysis of gut contents (Herzka and Holt, 2000; Pinnegar et al., 2001). Stable isotope analysis has emerged as a powerful tool to trace dietary sources, as the isotope ratios of a consumer are related to those of their food (DeNiro and Epstein, 1978, 1981; Peterson and Fry, 1987). This method provides an integrated measure of the dietary components over a much longer period of time than gut content analysis. Although stable isotope analysis does not provide a detailed picture of dietary preferences, it gives an average estimate of an organism's preferred diet that is less subject to temporal bias (Pinnegar and Polunin, 1999). 
The carbon and nitrogen isotope values (in delta notation, $\delta^{13} \mathrm{C}$ and $\delta^{15} \mathrm{~N}$ ) differ between organisms and their diets because of small but measurable selective retention of the heavier isotope and excretion of the lighter one. Typically, with each trophic transfer between a consumer and its diet, $\delta^{15} \mathrm{~N}$ values increase by approximately $3-5 \%$ (DeNiro and Epstein, 1981; Minigawa and Wada, 1984). On the other hand, an animal has $\delta^{13} \mathrm{C}$ values close to that of its diet with, however, a slight enrichment of $1 \%$ (DeNiro and Epstein, 1978; Tieszen et al., 1983; Hobson and Clark, 1992). $\delta^{13} \mathrm{C}$ values, rather than serving as reliable indicator of trophic level, is generally used to indicate the relative contributions of different potential primary sources to a local food web (Rau et al., 1992; Das et al., 2000, 2003). Hence, reef fish that leave their pelagic environment and settle in the reef might have a different $\delta^{13} \mathrm{C}$ and $\delta^{15} \mathrm{~N}$ signature resulting from a shift in both their diet and foraging areas (Bosley et al., 2002).

The first objective of this study is to confirm the commensal or parasitic status usually attributed to the Carapus and Encheliophis, respectively. $\delta^{13} \mathrm{C}$ and $\delta^{15} \mathrm{~N}$ measurements will be realised in the tissues of adult Carapus mourlani (Petit, 1934), Carapus boraborensis (Kaup, 1856), C. homei (Richardson, 1844) and Encheliophis gracilis (Bleeker, 1856) Bohadschia argus (Jaeger, 1833) and Culcita novaeguineae (Muller and Troschel, 1842). Since C. boraborensis, C. homei and E. gracilis live in the same lagoon and inhabit the same holothurian species, while $C$. mourlani is found in the coelomic cavity of the sea star $C$. novaeguineae, it will be possible to examine and contrast symbiotic strategies among fish species.

The second objective is to determine, on the basis of isotopic signatures, if the larvae feed on their host to achieve their metamorphosis or if the latter is realised without any exogenous food supply, as previously suggested (Parmentier et al., in press).

\section{Materials and methods}

Adult specimens of C. mourlani, C. boraborensis, C. homei and E. gracilis were collected in front of the Opanohu Bay, Moorea, French Polynesia in July and August 2000 and 2002. The specimens of C. mourlani were found in the coelomic cavity of C. novaeguineae (Asterid), and the three others were either in the coelomic cavity or in the respiratory trees of $B$. argus (Holothuroid). These echinoderms were collected by scuba diving at depths ranging from 3 to $20 \mathrm{~m}$. Juveniles and tenuis of $C$. boraborensis and $C$. homei were also found in $B$. argus. During the same period, $C$. homei tenuis were caught during the night when they arrived on the reef crest. The net used $(1.5 \mathrm{~m}$ wide $\times 0.75 \mathrm{~m}$ height $\times 5 \mathrm{~m}$ length, 1 -mm-wide mesh net $)$ is similar to one of those used by Dufour et al. (1996). According to Parmentier et al. (2002b), tenuis are settling larval fish: their total body length ranges from 19 to $23 \mathrm{~cm}$. Specimens undergoing their metamorphosis display a body length from 23 to $6 \mathrm{~cm}$. After metamorphosis, fish are considered as juveniles and their body length varies from 6 to $8 \mathrm{~cm}$. All the adults captured in this study had a length superior to $12 \mathrm{~cm}$. Within an aquarium, two tenuis of $C$. homei each entered into holothurians (B. argus); each tenuis was left inside its host during 15 days without providing food. Unfortunately, no E. gracilis tenuis were found during the field samplings. 
Seawater samples were filtered trough precombusted glass filters (Whatman GK/F) $\left(450{ }^{\circ} \mathrm{C}, 4 \mathrm{~h}\right)$ for the isotopic analysis of particulate organic matter (POM). Gonads and respiratory trees were selected for stable isotope analysis because these tissues are usually found in the stomach content of parasitic carapids (Vanden Spiegel and Jangoux, 1989). Holothurian and starfish digestive tract, muscle and digestive gland were also analysed, as fish could easily be preyed upon above the general cavity. Starfish podia were also sampled.

For adult and juvenile fish analysis, only white muscles were used, as this tissue is considered as the most suitable (Pinnegar and Polunin, 1999). Due to the small size of the tenuis, white muscle could not be separated from the body and therefore the whole posterior part (without the abdominal cavity) was ground.

Samples were dehydrated during $24 \mathrm{~h}$ at $50{ }^{\circ} \mathrm{C}$ and the different samples were ground into a homogenous powder. To eliminate $\mathrm{CaCO}_{3}$, holothurian and starfish teguments and tenuis tissues were first decalcified during $4 \mathrm{~h}$ in $1 \mathrm{M} \mathrm{HCl}$. When samples were acidified, ${ }^{15} \mathrm{~N} /{ }^{14} \mathrm{~N}$ ratios were measured before acidification, due to significant modifications of these ratios after $\mathrm{HCl}$ treatment (Pinnegar and Polunin, 1999).

Carbon and nitrogen gas were analysed on a V.G. Optima (Micromas) IP-MS coupled to a N-C-S elemental analyser (Carbo Erba). Routine measurements are precise to within $0.3 \%$ for both $\delta^{13} \mathrm{C}$ and $\delta^{15} \mathrm{~N}$. Stable isotope ratios were expressed in $\delta$ notation according to the following:

$$
\delta X=\left[\left(R_{\text {sample }} / R_{\text {standard }}\right)-1\right] \times 1000
$$

where $X$ is ${ }^{13} \mathrm{C}$ or ${ }^{15} \mathrm{~N}$ and $R$ is the corresponding ratio ${ }^{13} \mathrm{C} /{ }^{12} \mathrm{C}$ or ${ }^{15} \mathrm{~N} /{ }^{14} \mathrm{~N}$.

Carbon and nitrogen ratios are expressed relative to the VPDB (Vienna Peedee Belemnite) standard and to atmospheric nitrogen, respectively. Reference materials were IAEA-N1 $\left(\delta^{15} \mathrm{~N}=+0.4 \pm 0.2 \%\right.$ ) and IAEA CH-6 (sucrose) $\left(\delta^{13} \mathrm{C}=-10.4 \pm 0.2 \%\right.$ )

\subsection{Data treatment}

Kolmogorov-Smirnov test was used to test the normality of the data. One wayANOVA followed by post hoc multiple comparison tests (Tukey test) was used to compare the data on the different species (fish and invertebrates) and also on the different age groups (tenuis, juveniles and adults).

\section{Results}

The isotopic composition of particulate organic matter (POM), echinoderms and fish from the Moorea Lagoon are summarised in Table 1. After their $\delta^{13} \mathrm{C}$ and $\delta^{15} \mathrm{~N}$ mean values, three groups could be distinguished (Fig. 1). The first group included C. homei, $C$. boraborensis and $C$. mourlani adult fishes. These three species were characterised by a high $\delta^{15} \mathrm{~N}$ mean values compared to the second (POM) and third group (the three invertebrates and the fish E. gracilis). 
Table 1

$\delta^{13} \mathrm{C}$ and $\delta^{15} \mathrm{~N}$ values (mean and standard deviation) in carapid fish, selected invertebrates and particulate organic matter (POM) from the Opanohu Bay (Moorea)

\begin{tabular}{|c|c|c|c|c|c|}
\hline & Species & Tissue & $n$ & $\delta^{13} \mathrm{C}(\% \circ)$ & $\delta^{15} \mathrm{~N}(\% \circ)$ \\
\hline POM & & & 3 & $-19.8 \pm 0.9$ & $6.4 \pm 2.3$ \\
\hline \multirow[t]{9}{*}{ Echinoderms } & \multirow[t]{5}{*}{ Bohadschia argus } & muscle & 19 & $-7.7 \pm 1.9$ & $5.3 \pm 1.5$ \\
\hline & & digestive tract & 21 & $-10.8 \pm 2$ & $4.9 \pm 1.3$ \\
\hline & & digestive gland & 18 & $-12.5 \pm 3.2$ & $4.0 \pm 1.5$ \\
\hline & & respiratory tree & 15 & $-8.75 \pm 1.9$ & $6.6 \pm 1.1$ \\
\hline & & gonads & 23 & $-11.9 \pm 2.1$ & $4.8 \pm 2$ \\
\hline & \multirow[t]{4}{*}{ Culcita novaeguineae } & digestive gland & 3 & $-13.2 \pm 2.2$ & $6.7 \pm 1.6$ \\
\hline & & gonads & 3 & $-10.0 \pm 1.3$ & $6.9 \pm 1$ \\
\hline & & podia & 3 & $-8.1 \pm 1.4$ & $8.6 \pm 2.8$ \\
\hline & & stomach & 3 & $-11.1 \pm 0.6$ & $7.6 \pm 1.1$ \\
\hline \multirow[t]{9}{*}{ Carapidae } & \multirow[t]{3}{*}{ Carapus boraborensis } & adult-muscle & 6 & $-16.6 \pm 1.9$ & $12.3 \pm 0.7$ \\
\hline & & settling tenuis & 3 & $-17.9 \pm 0.5$ & $10.8 \pm 0.4$ \\
\hline & & juveniles-muscle & 5 & $-19.9 \pm 1.9$ & $11.8 \pm 1.1$ \\
\hline & \multirow[t]{4}{*}{ Carapus homei } & adult-muscle & 5 & $-18.0 \pm 0.8$ & $13.8 \pm 1$ \\
\hline & & settling tenuis & 5 & $-19.2 \pm 0.6$ & $13 \pm 1.6$ \\
\hline & & metamorphosing tenuis & 4 & $-19 \pm 0.5$ & $13.3 \pm 1.6$ \\
\hline & & experimental tenuis & 2 & $-19 \pm 0.3$ & $15.2 \pm 1.8$ \\
\hline & Carapus mourlani & adult-muscle & 3 & $-18.2 \pm 0.9$ & $13.9 \pm 2.1$ \\
\hline & Encheliophis gracilis & adult-muscle & 2 & $-10.1 /-7.6$ & $6.2-8.3$ \\
\hline
\end{tabular}

\subsection{Adult fish relationships}

Muscle mean $\delta^{15} \mathrm{~N}$ values differed significantly between the four fish species (ANOVA, $\left.F_{3,12}=16.8, p<0.0001\right)$. Specifically, E. gracilis displayed significantly lower $\delta^{15} \mathrm{~N}$ values

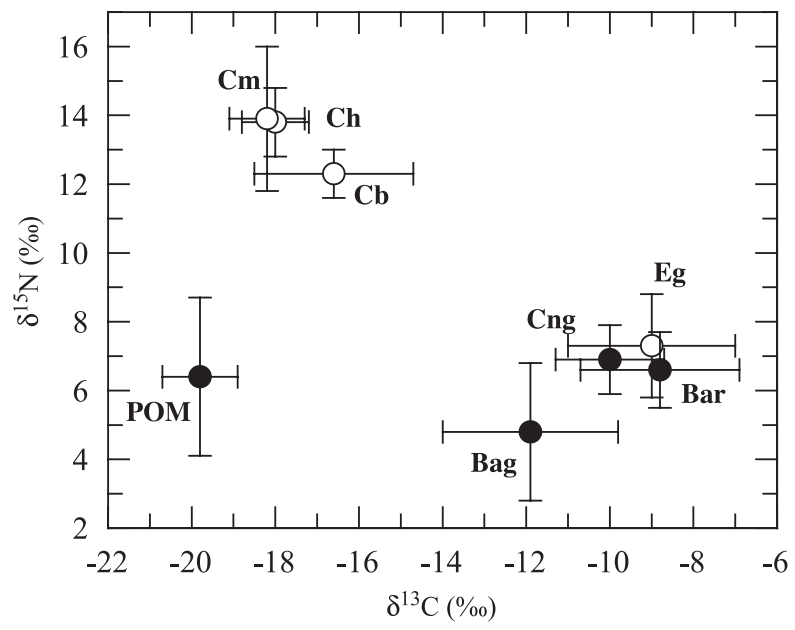

Fig. 1. $\delta^{13} \mathrm{C}$ and $\delta^{15} \mathrm{~N}$ values (mean and standard deviation) of carapid adult fish (white dots), selected invertebrates and particulate organic matter (black dots) from Opanohu Bay (Moorea). $\mathrm{Cb}$; muscle of $C$. boraborensis; Ch: muscle of C. homei; Cm: muscle of C. mourlani; Eg: muscle of E. gracilis; Cng: gonad of $C$. novaeguineae; Bag: gonad of B. argus; POM: particulate organic matter. 
than that of $C$. mourlani (post hoc test, $p<0.0001), C$. homei $(p<0.0001)$ and $C$. boraborensis $(p<0.002$, Fig. 1$) . \delta^{15} \mathrm{~N}$ values were similar for $C$. boraborensis, $C$. homei and $C$. mourlani $(p>0.1)$.

Muscle mean $\delta{ }^{13} \mathrm{C}$ differed significantly between fish species (ANOVA, $F_{3,12}=20.3$, $p<0.0001)$. E. gracilis was significantly enriched in ${ }^{13} \mathrm{C}$ compared to the values of $C$. mourlani (post hoc test, $p<0.0003)$, C. homei $(p<0.0003)$ and $C$. boraborensis $(p<0.005$, Fig. 1). $\delta^{13} \mathrm{C}$ values were similar for $C$. boraborensis, $C$. homei, and $C$. mourlani $(p>0.4)$.

\subsection{Fish-invertebrate relationships}

$\delta^{13} \mathrm{C}$ and $\delta^{15} \mathrm{~N}$ signatures of the holothurian gonads and respiratory trees were significantly different (ANOVA, Tukey test, $p<0.005$ and $p<0.01$ for $\delta^{13} \mathrm{C}$ and $\delta^{15} \mathrm{~N}$, respectively). C. homei and $C$. boraborensis tissues were strongly ${ }^{13} \mathrm{C}$-depleted compared to the muscles, digestive tract and glands, respiratory trees and gonads of their holothurian host, $B$. argus (ANOVA, $p<0.0005$ ). A similar ${ }^{13} \mathrm{C}$ depletion was observed for $C$. mourlani muscle compared to the different tissues of the starfish host $C$. novaeguineae (ANOVA, $p<0.0001$ ).

$\delta{ }^{13} \mathrm{C}$ values did not differ significantly between $E$. gracilis muscle and the different tissues of the holothurian $B$. argus. In contrast, E. gracilis displayed a mean $\delta^{15} \mathrm{~N}$ enrichment of $0.9 \%$ and $2.5 \%$, compared to B. argus respiratory trees and gonads, respectively (Table 1$)$.

\subsection{Tenuis, juvenile and adult fish comparison}

C. boraborensis juveniles are ${ }^{13} \mathrm{C}$-depleted compared to adults (ANOVA, post hoc test, $p<0.05)$, while $\delta^{15} \mathrm{~N}$ values were similar among tenuis, juveniles and adults $(p>0.2)$. C.

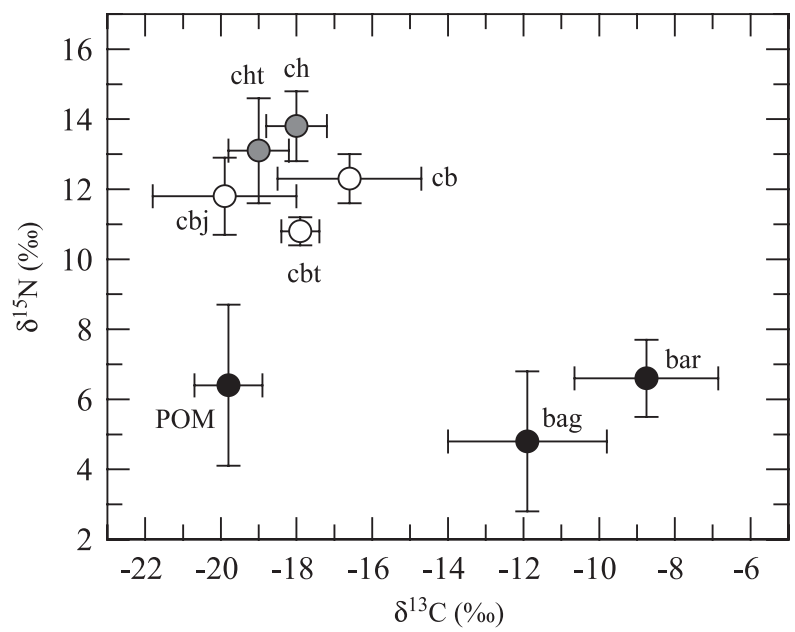

Fig. 2. $\delta^{13} \mathrm{C}$ and $\delta^{15} \mathrm{~N}$ (mean and standard deviation) values of selected invertebrates, particulate organic matter (black dots) and tenuis, juveniles, and adult carapid from Opanohu Bay (Moorea). Cbt, Cbj and $\mathrm{Cb}$ : tenuis, juvenile and adult of $C$. boraborensis (white dots); Cht and Ch: tenuis and adult of $C$. homei (grey dots); Bag and Bar: gonad and respiratory tree of B. argus; POM: particulate organic matter. 
homei tenuis and adults displayed similar $\delta^{13} \mathrm{C}$ and $\delta^{15} \mathrm{~N}$ values $(p>0.05)$. (Table 1 and Fig. 2).

\section{Discussion}

Previous studies have shown that $90 \%$ of the stomach of Carapini are empty, while the remaining 10\% contain annelids, crustaceans (shrimps, decapods, amphipods, copepods) and small fish (Trott, 1970; Meyer-Rochow, 1979; Vanden Spiegel and Jangoux, 1989). This high percentage of empty stomach could be misleading, as holothurian tissues could be digested faster than organisms having an exo- or endoskeleton and would therefore not be detected during gut content analysis.

\subsection{Relationship between Carapidae adults and their host}

A $\delta^{15} \mathrm{~N}$ mean enrichment of $2.5 \%$ is observed between the holothurian gonads and $E$. gracilis muscles, which is in the same order of values reported previously between a predator and its prey (DeNiro and Epstein, 1978; Minigawa and Wada, 1984; Vander Zanden and Hulshof, 1998; Vizzini and Mazzola, 2002). These data strongly suggest that E. gracilis, in contrast to other carapids, could prey upon holothurian gonads, confirming results obtained by previous stomach contents studies (Smith, 1964; Trott, 1970, 1981; Trott and Trott, 1972; Murdy and Cowan, 1980) and skull morphofunctional studies (Vandewalle et al., 1998; Parmentier et al., 1999, 2000b). The $\delta^{15} \mathrm{~N}$ (and $\delta^{13} \mathrm{C}$ ) trophic enrichment of a parasite relative to its host has also been reported for other types of parasites (Boag et al., 1998; Doucett et al., 1999), but is not systematic and some fish parasites (cestode, nematode, isopode, copepode) are even depleted compared to their host (Pinnegar et al., 2001). The ${ }^{15} \mathrm{~N}$-enrichment observed between the holothurian and $E$. gracilis corresponds to a typical trophic enrichment between a prey and a fish predator. From an ecological point of view, E. gracilis is considered to be a parasite, such as some cestode, nematode and isopode species. However, metabolic pathways displayed by vertebrates such as this carapid are likely to be very different from those encountered in other invertebrates parasites, leading to a differential fractionation between different kinds of parasitism (Pinnegar et al., 2001). The definition of ecological parasitism and trophic parasitism should therefore be differentiated.

In contrast to $E$. gracilis, $C$. boraborensis and $C$. homei adults are isotopically similar. Their marked ${ }^{15} \mathrm{~N}$ enrichment and their ${ }^{13} \mathrm{C}$ depletion compared to E. gracilis, the holothurian, and the starfish are not consistent with a parasitic feeding behaviour. Although isotopic measurements were not performed in the potential prey of $C$. boraborensis and $C$. homei, their isotopic signature is significantly different from that of the parasite E. gracilis, which lives in both the same lagoon and holothurian host species. C. boraborensis and C. homei are likely to use their host as a shelter and leave it to hunt prey within the lagoon. These results confirm the commensal relationship usually attributed to these fish on the basis of gut contents and morphological characters (Smith, 1964; Trott, 1970; Trott and Trott, 1972; Parmentier et al., 1998, 2000b). Moreover, isotopic measurements also confirm the commensal behaviour of C. mourlani. Indeed, 
crabs and polychaetes (but no echinoderm tissues) were previously recorded in the $C$. mourlani gut content (Meyer-Rochow, 1979).

\subsection{Relationship between Carapus larvae and their host}

Fish larvae usually display a different isotopic signature before and after their settlement because the transition phase corresponds to a diet shift (Hesslein et al., 1993; Vander Zanden and Hulshof, 1998; Bosley et al., 2002; Herzka et al., 2001, 2002; Cocheret de la Morinière et al., 2003). A fast change (within 4 days) in isotopic composition linked to a diet shift has been previously observed for the winter flounder (Pseudopleuronectes americanus) during its metamorphosis (Bosley et al., 2002).

As the whole tenuis metamorphosis is achieved in the holothurian, larvae feeding on their host should have a typical and different isotopic signature from that displayed by tenuis before penetration. This is obviously not the case: no isotopic differences were observed in Carapus larvae before or after their settlement in the holothurian. Similarly, there were no significant isotopic differences between the tenuis metamorphosed in the aquarium and fish metamorphosed in the wild.

On the other hand, holothurian tissue is likely to be the only available food source during the fish metamorphosis. The absence of change in isotopic composition could also indicate that the tenuis do not feed at all during its metamorphosis. These results enhance the hypothesis of a re-use of the metabolites resulting from the degradation of the posterior part of the body in order to realise the metamorphosis (Parmentier et al., 2002a). The metabolic turnover involves the degradation and replacement of existing body tissues. So its effect will only be detectable using stable isotope ratios if the degraded material is replaced through de novo synthesis, rather than recycled (Herzka et al., 2001). The lack of modification in $\delta^{13} \mathrm{C}$ and $\delta^{15} \mathrm{~N}$ measurements has been described previously in starved fish (Herzka and Holt, 2000) and in other poikilotherms such as shrimp (Frazer et al., 1997; Gorokhova and Hansson, 1999).

\subsection{Further information on the Carapus life}

The $\delta^{13} \mathrm{C}$ and $\delta^{15} \mathrm{~N}$ values observed for the POM correspond to that observed for oceanic POM at these latitudes (Johnston and Kennedy, 1998; Hofmann et al., 2000; Davenport and Bax, 2002; Guo et al., 2002). The $\delta^{13} \mathrm{C}$ values observed for the larvae are close to those of the POM (Fig. 2), which is in good agreement with a planktonic diet (Blamart et al., 2002). The isotopic values of the POM are typically oceanic and reflect the wide exchange between the lagoon and the ocean (Yamamouro et al., 1995). However, the Carapus adults are ${ }^{13} \mathrm{C}$-depleted compared to the lagoon benthic invertebrates (Guo et al., 2002). Strikingly, $\delta^{13} \mathrm{C}$ values displayed by $C$. homei and $C$. boraborensis adults (from $-15.8 \%$ o to $-18 \%$ ) reflect a diet including prey depleted in ${ }^{13} \mathrm{C}$, such as pelagic prey or organisms just arrived in the lagoon. Indeed, stable carbon isotope ratios have proven most useful in identifying where particular organisms feed, as $\delta^{13} \mathrm{C}$ values are typically higher in species from coastal or benthic food webs than in offshore food webs (Hobson and Clark, 1992; Lesage et al., 2001). In a similar coral reef ecosystem, annelids and gastropods were

similarly ${ }^{13} \mathrm{C}$-enriched compared to the POM $(-18.6 \%$ ) and filter feeders $(-12 \%$ ) such 
as the mollusc Tricadna sp. ( $-15 \%$ ) (Guo et al., 2002). Furthermore, fish such as the Serranidae Epinephelus merra and the Labridae Halichoeres centiquadrus, feeding on benthic prey are also ${ }^{13} \mathrm{C}$-enriched $(-11.9 \%$ to $-10.9 \%$ o $)$ compared to the Beloniforme Tylosurus melanotus feeding on pelagic prey (-16.6\%o) (Guo et al., 2002).

During the fish growth, the isotope ratios fractionation appears to be linked to the metabolism. The lower the metabolism, the lower the fractionation (Herzka and Holt, 2000; Focken, 2001). Although direct studies of the metabolic activity were not realised, combined field observations (Meyer-Rochow, 1977; Smith et al., 1981) and studies of the fish otolith increments (Parmentier et al., 2002a) indicate that the Carapus may stay inside their host for long periods of time (several days to more than 2 months) that do not require a high metabolism. The isotopic signature of the adult Carapus could also indicate that their diet is mainly based on pelagic preys or newly settled organisms. For instance, adult Carapus has been described as cannibalistic and to feed on pelagic Carapus larvae that enter their host for the first time (Smith et al., 1981).

\section{Conclusions}

$\delta^{13} \mathrm{C}$ and $\delta^{15} \mathrm{~N}$ measurements appeared as a useful tool to characterise the trophic status of Carapidae fishes and selected invertebrates from the Moorea lagoon. Our results further confirm the commensal and parasitic feeding behaviour of the Carapus species and E. gracilis, respectively. More important, the isotopic data of C. boraborensis and C. homei tenuis highlight the fact that these larvae do not feed on their host tissues, but remobilise their own tissues to achieve their metamorphosis. Further research on other organisms from this area would help to get a better understanding of the different alimentary relationships within the Moorea Lagoon.

\section{Acknowledgements}

We thank R. Galzin, Y. Chancerelle and J. Algret (CRIOBE, Moorea, French Polynesia), V. Dufour of Aquafish Polynesia for helping to obtain living Carapidae. Christophe Brié, of Aquafish Rangiroa, kindly accepted our realising a part of this study in its installation (Rangiroa). We also thank R. Biondo, G. Lepoint and R. Bouhy for help with the isotopic analysis composition. We are grateful to P. Vandewalle and J.M. Bouquegneau for useful remarks and help. This work was supported by grant No. 2.4560.96 from the «Fonds National de la Recherche Scientifique» of Belgium and by grant BVCONV028 (Concours des bourses de voyages, Communauté Franç aise de Belgique). This is Mare publication no. 039. [SS]

\section{References}

Arnold, D.C., 1953. Observation on Carapus acus (Brünnich) (Jugulares, Carapidae). Pubbl. Stn. Zool. Napoli 24, $152-166$.

Blamart, D., Escoubeyrou, K., Juillet-Leclers, A., Ouahdi, R., Lecomte-Finiger, L., 2002. Composition isotopi- 
que $\delta^{18} \mathrm{O}-\delta{ }^{13} \mathrm{C}$ des otolithes des populations de poisons récifaux de Taiaro (Tuamotu, Polynésie française): implications isotopiques et biologiques. C.R. Biol. 325, 99-106.

Boag, B., Neilson, R., Robinson, D., Scrimgeour, C.M., Handley, L.L., 1998. Wild rabbit host and some parasites show trophic-level relationships for $\delta^{13} \mathrm{C}$ and $\delta^{15} \mathrm{~N}$ : a first report. Isot. Environ. Health Stud. 34, 81-85.

Bonhomme, F., Planes, S., 2000. Some evolutionary arguments about what maintains the pelagic interval in reef fishes. Environ. Biol. Fisches 59, 365-383.

Bosley, K.L., Witting, D.A., Chambers, R.C., Wainright, S.C., 2002. Estimating turnover rates of carbon and nitrogen in recently metamorphosed winter flounder Pseudopleuronectes americanus with stable isotopes. Mar. Ecol. Prog. Ser. (Halstenbek) 236, 233-240.

Cocheret de la Morinière, E., Pollux, B.J.A., Nagelkerken, I., Hemminga, M.A., Huiskes, A.H.L., van der Velde, G., 2003. Ontogenic dietary changes of coral reef fishes in the mangrove-seagrass-reef continuum: stable isotopes and gut-content analysis. Mar. Ecol. Prog. Ser. (Halstenbek) 246, 279-289.

Das, K., Lepoint, G., Loizeau, V., Debacker, V., Dauby, P., Bouquegneau, J.M., 2000. Tuna and dolphin associations in the Northeast Atlantic: evidence of different ecological niches from stable isotope and heavy metal measurements. Mar. Pollut. Bull. 40, 102-110.

Das, K., Lepoint, G., Leroy, Y., Bouquegneau, J.M., 2003. Marine mammals from the southern North Sea: feeding ecology data from $\delta{ }^{13} \mathrm{C}$ and $\delta^{15} \mathrm{~N}$ measurements. Mar. Ecol. Prog. Ser. (Halstenbek) 263, $287-298$.

Davenport, S.R., Bax, N.J., 2002. A trophic study of a marine ecosystem off southeastern Australia using stable isotopes of carbon and nitrogen. Can. J. Fish. Aquat. Sci. 59, 514-530.

DeNiro, M.J., Epstein, S., 1978. Influence of the diet on the distribution of carbon isotopes in animals. Geochim. Cosmochim. Acta 42, 495-506.

DeNiro, M.J., Epstein, S., 1981. Influence of diet on the distribution of nitrogen isotopes in animals. Geochim. Cosmochim. Acta 45, 341-351.

Doucett, R.R., Giberson, D.J., Power, G., 1999. Parasitic association of Nanocladius (Diptera: Chironomidae) and Pteronarcys biloba (Plecoptera: Pteronarcydae): insights from stable-isotope analysis. J.N. Am. Benthol. Soc. $18,523-541$.

Dufour, V., Riclet, E., Lo-Yat, A., 1996. Colonization of reef fishes at Moorea Island, French Polynesia: temporal and spatial variation of the larva flux. N.Z. J. Mar. Freshw. Res. 47, 413-422.

Frazer, T.K., Ross, R.M., Quetin, L.B., Montoya, J.P., 1997. Turnover of carbon and nitrogen during growth of larval krill, Euphasia superba Dana: a stable isotope approach. J. Exp. Mar. Biol. Ecol. 212, 259-275.

Focken, U., 2001. Stable isotopes in animal ecology: the effect of ration size on the trophic shift of $\mathrm{C}$ and $\mathrm{N}$ isotopes between feed and carcass. Isot. Environ. Health Stud. 37, 199-211.

Gorokhova, E., Hansson, S., 1999. An experimental study on variations in stable carbon and nitrogen isotope fractionation during growth of Mysis mixta and Neomysis integer. Can. J. Fish. Aquat. Sci. $56,2203-2210$.

Govoni, J.J., Olney, J.E., Markle, D.F., Curtsinger, W.R., 1984. Observations on structure and evaluation of possible functions of the vexillum in larval Carapidae (Ophidiiformes). Bull. Mar. Sci. 34, 60-70.

Guo, W., Yang, Y., Wu, L., Wang, H., Hu, M., 2002. Carbon isotope study on trophic relationships of Zhubi reef ecosystem in Nansha Islands. J. Oceanogr., Taiwan 21, 94-101.

Gustato, G., 1976. Osservazioni sulla biologica e sul comportamento di Carapus acus (Ophioidei Percomorphi). Boll. Soc. Nat. Napoli 85, 505-535.

Herzka, S.Z., Holt, G.J., 2000. Changes in isotopic composition of red drum (Sciaenops ocellatus) larvae in response to dietary shifts: potential applications to settlement studies. Can. J. Fish. Aquat. Sci. 57, $137-147$.

Herzka, S.Z., Holt, S.A., Holt, G.J., 2001. Documenting the settlement history of individual fish larvae using stable isotope ratios: model development and validation. J. Exp. Mar. Biol. Ecol. 265, 49-74.

Herzka, S.Z., Holt, S.A., Holt, G.J., 2002. Characterization of settlement patterns of red drum Sciaenops ocellatus larvae to estuarine nursery habitat: a stable isotope approach. Mar. Ecol. Prog. Ser. (Halstenbek) 226, $143-156$.

Hesslein, R.H., Hallard, K.A., Ramlal, P., 1993. Replacement of sulfur, carbon, and nitrogen in tissue of growing broad whitefish (Coregonus nasus) in response to a change in diet traced by $\delta^{34} \mathrm{~S}, \delta^{13} \mathrm{C}$, and $\delta^{15} \mathrm{~N}$. Can. J. Fish. Aquat. Sci. 50, 2071-2076.

Hobson, K.A., Clark, R.G., 1992. Assessing avian diets using stable isotope II: factors influencing diet-tissue fractionation. Condor 94, 189-197. 
Hofmann, M., Wolf-Gladrow, D.A., Takahashi, T., Sutherland, S.C., Six, K.D., Maier-Reimer, E., 2000. Stable carbon isotope distribution of particle organic matter in the ocean: a model study. Mar. Chem. 72, 131-150.

Jangoux, M., 1974. Sur l'association entre certaines astéries (Echinodermata) et des poissons Carapidae. Rev. Zool. Afr. 88, 789-796.

Johnston, A.M., Kennedy, H., 1998. Carbon stable isotope fractionation in marine systems: open ocean studies and laboratory studies. In: Griffiths, H. (Ed.), Stable Isotopes, Integration of Biological, Ecological and Geochemical Processes. Published in the Environmental Plant Biology. BIOS Scientific Publishers, Oxford, pp. 239-256.

Leis, J.M., McCormick, M.I., 2002. The biology, behavior, and ecology of the pelagic, larval stage of coral reef fishes. In: Sale, P.F. (Ed.), Coral Reef Fishes: New Insights into their Ecology. Academic Press, San Diego, pp. $171-209$.

Lesage, V., Hammill, M.O., Kovacs, K.M., 2001. Marine mammals and the community structure of the estuary and Gulf of St Lawrence, Canada: evidence from stable isotope analysis. Mar. Ecol. Progr. Ser. (Halstenbek) 210, 203-221.

Markle, D.F., Olney, J.E., 1990. Systematics of the pearlfish (Pisces: Carapidae). Bull. Mar. Sci. 47, 269-410.

McCormick, M.I., Makey, L.J., 1997. Post-settlement transition in coral reef fishes: overlooked complexity in niche shifts. Mar. Ecol., Prog. Ser. (Halstenbek) 153, 247-257.

Meyer-Rochow, V.B., 1977. Comparison between 15 Carapus mourlani in a single Holoturian and 19 Carapus mourlani from starfish. Copeia, 582-585.

Meyer-Rochow, V.B., 1979. Stomach and gut content of Carapus mourlani from starfish and a holothurian. Ann. Zool. Fenn. 16, 287-289.

Minigawa, M., Wada, E., 1984. Stepwise enrichment of $\delta^{15} \mathrm{~N}$ along food chains: further evidence and the relation between $\delta^{15} \mathrm{~N}$ and animal age. Geochim. Cosmoch. Acta 48, 1135-1140.

Motta, P.J., Clifton, K.B., Hernandez, P., Eggold, B.T., 1995. Ecomorphological correlates in ten species of subtropical seagrass fishes: diet and microhabitat. Environ. Biol. Fisches 44, 37-60.

Murdy, E.O., Cowan, M.E., 1980. Observation on the behaviour and symbiotic relationship of the pearlfish Encheliophis vermicularis (Osteichthys: Carapidae). Kalikasan, Philipp. J. Biol. 9, 309-312.

Norton, S.F., Luczkovich, J.J., Motta, P.J., 1995. The role of ecomorphological studies in the comparative biology of fishes. Environ. Biol. Fisches 44, 287-304.

Olney, J.E., Markle, D.F., 1979. Description and occurrence of vexillifer larvae of Echiodon (Pisces: Carapidae) in the western North Atlantic and notes on other carapid vexillifers. Bull. Mar. Sci. 29, $365-379$.

Parmentier, E., Chardon, M., Poulicek, M., Bussers, J.C., Vandewalle, P., 1998. Morphology of the buccal apparatus and related structures in four species of Carapidae. Aust. J. Zool., Suppl. Ser. 46, 391-404.

Parmentier, E., Chardon, M., Poulicek, M., Bussers, J.C., Vandewalle, P., 1999. Morphological particularities of the head in four Carapidae (Ophidiiformes). In: Séret, B., Sire, J.Y. (Eds.), Proc 5th Indo-Pacific Conf., Nouméa, 1997. Soc. Fr. Ichthyol., Paris, pp. 135-146.

Parmentier, E., Castillo, G., Chardon, M., Vandewalle, P., 2000a. Phylogenetic analysis of the pearlfish tribe Carapini (Pisces: Carapidae). Acta Zool. 81, 293-306.

Parmentier, E., Castro-Aguirre, J.L., Vandewalle, P., 2000b. Morphological comparison of the buccal apparatus in two bivalve commensal Teleostei: Encheliophis dubius and Onuxodon fowleri (Carapidae, Ophidiiformes). Zoomorphology 120, 29-37.

Parmentier, E., Lagardère, F., Vandewalle, P., 2002a. Relationships between inner ear and sagittal growth during ontogenesis of three Carapini species and consequences of life-history events on the otolith microstructure. Mar. Biol. 141, 491-501.

Parmentier, E., Lo-Yat, A., Vandewalle, P., 2002b. Identification of four French Polynesia tenuis Carapini (Carapidae: Teleostei). Mar. Biol. 140, 633-638.

Parmentier, E., Lecchini, D., Lagardère, F. Vandewalle, P., in press. Ontogenic and ecological control of metamorphosis onset in a carapid fish, Carapus homei: experimental evidence from vertebra and otolith comparisons. J. Exp. Zool.

Peterson, B.J., Fry, B., 1987. Stable isotopes in ecosystem studies. Ann. Rev. Ecolog. Syst. 18, $293-320$.

Pinnegar, J.K., Polunin, N.V.C., 1999. Differential of $\delta^{13} \mathrm{C}$ and $\delta^{15} \mathrm{~N}$ among fish tissues: implications for the study of trophic interactions. Funct. Ecol. 13, 225-231. 
Pinnegar, J.K., Campbell, N., Polunin, N.V.C., 2001. Unusual stable isotope fractionation patterns observed for fish host-parasite trophic relationships. J. Fish Biol. 59, 494-503.

Rau, G.H., Ainley, D.G., Bengtson, J.L., Torres, J.J., Hopkins, T.L., $1992 .{ }^{15} \mathrm{~N} /{ }^{14} \mathrm{~N}$ and ${ }^{13} \mathrm{C} /{ }^{12} \mathrm{C}$ in Weddell seabirds, seals, and fish: implications for diet and trophic structure. Mar. Ecol. Prog. Ser. (Halstenbek) 84, $1-8$.

Smith, C.L., 1964. Some pearlfishes from Guam, with notes on their ecology. Pac. Sci. 18, 34-40.

Smith, C.L., Tyler, J.C., Feinberg, M.N., 1981. Population ecology and biology of the pearlfish (Carapus bermudensis) in the lagoon at Bimini, Bahamas. Bull. Mar. Sci. 3, 876-902.

Tieszen, L.L., Boutton, T.W., Tesdahl, K.G., Slade, N.A., 1983. Fractionation and turn-over of stable carbon isotopes in animal tissues: implication for $\delta^{13} \mathrm{C}$ analysis of diet. Oecologia 57, 32-37.

Trott, L.B., 1970. Contribution of the biology of Carapid fishes (Paracanthopterygian: Gadiformes). Univ. Calif. Publ. Zool. 89, 1-41.

Trott, L.B., 1981. A general review of the pearlfishes (Pisces, Carapidae). Bull. Mar. Sci. 31, 623-629.

Trott, L.B., Trott, E.B., 1972. Pearlfishes (Carapidae: Gadiforme) collected from Puerto Galera, Mindoro, Philippines. Copeia, 839-843.

Vanden Spiegel, D., Jangoux, M., 1989. La symbiose entre poissons Carapidae et Holoturies autour de l'île de Laing (Mer de Bismarck, Papouasie Nouvelle Guinée). Indo-Malayan Zool. 6, 223-228.

Vander Zanden, M.J., Hulshof, M., 1998. Application of stable isotope techniques to trophic studies of age-0 smallmouth bass. Trans. Am. Fish. Soc. 127, 729-739.

Vandewalle, P., Parmentier, E., Poulicek, M., Bussers, J.C., Chardon, M., 1998. Distinctive anatomical features of the branchial basket in four Carapidae species (Ophidiiformi, Paracanthopterygii). Europ. J. Morph. 36, $153-164$.

Vizzini, S., Mazzola, A., 2002. Stable carbon and nitrogen ratios in the sand smelt from a Mediterranean coastal area: feeding habits and effect of season and size. J. Fish Biol. 60, 1498-1510.

Wainwright, P.C., 1998. Morphology and ecology: functional basis of feeding constraints in Caribbean labrid fishes. Ecology 69, 635-645.

Yamamouro, M., Kayanne, H., Minagawa, M., 1995. Carbon and nitrogen stable isotopes of primary producers in coral reef ecosystems. Limnol. Oceanogr. 40, 617-621. 